\title{
Multinomial Logistic Regression to Estimate the Financial Education and Financial Knowledge of University Students in Chile
}

\author{
Hanns de la Fuente-Mella ${ }^{1}$ (D), Benito Umaña-Hermosilla ${ }^{2}$, Marisela Fonseca-Fuentes ${ }^{2, *(D)}$ \\ and Claudio Elórtegui-Gómez ${ }^{3}$ (D)
}

check for

updates

Citation: Fuente-Mella, H.d.l.; Umaña-Hermosilla, B.; FonsecaFuentes, M.; Elórtegui-Gómez, C. Multinomial Logistic Regression to Estimate the Financial Education and Financial Knowledge of University Students in Chile. Information 2021, 12, 379. https://doi.org/10.3390/ info12090379

Academic Editor: Gennady Agre

Received: 19 July 2021

Accepted: 30 August 2021

Published: 17 September 2021

Publisher's Note: MDPI stays neutral with regard to jurisdictional claims in published maps and institutional affiliations.

Copyright: (c) 2021 by the authors. Licensee MDPI, Basel, Switzerland. This article is an open access article distributed under the terms and conditions of the Creative Commons Attribution (CC BY) license (https:// creativecommons.org/licenses/by/ $4.0 /)$.
1 Escuela de Comercio, Facultad de Ciencias Económicas y Administrativas, Pontificia Universidad Católica de Valparaíso, Valparaíso 2340025, Chile; hanns.delafuente@pucv.cl

2 Departamento de Gestión Empresarial, Facultad de Ciencias Empresariales, Universidad del Bío-Bío, Chillán 2463334, Chile; benito@ubiobio.cl

3 Escuela de Periodismo, Facultad de Ciencias Económicas y Administrativas, Pontificia Universidad Católica de Valparaíso, Valparaíso 2373223, Chile; claudio.elortegui@pucv.cl

* Correspondence: mfonseca@ubiobio.cl

\begin{abstract}
All individuals face decisions during their lifetime that directly influence the economic well-being of their families. Therefore, financial education can be a fundamental tool to maximize our economic resources and use them wisely. A virtual survey was administered to 410 volunteer students belonging to a public university in southern Chile. The objective was to determine the level of financial knowledge and appreciation of financial education of future professionals. The most important results demonstrate a reality in which young people said they had the habit of saving and budgeting at home and were responsible for paying their bills on time. However, only a very small number of participants claimed having a superior level of knowledge regarding financial literacy. The main challenge for universities is to include this topic in the elective curriculum of all degree programs to promote financial criterion development that contributes to the comprehensive training and professional competencies of future graduates.
\end{abstract}

Keywords: financial education; financial knowledge; higher education; econometric modeling

\section{Introduction}

Globalization and the hectic pace of modern life have promoted a lifestyle in which immediacy and the standardization of needs are a driving force of consumerism among the population. In this context, our personal finances are confronted on a daily basis with the risk of indebtedness because of a growing supply of financial products, easy access to credit, and advertising and marketing strategies. Therefore, financial education is perceived as a tool to help achieve economic wellbeing by maximizing monetary resources [1], and is a fundamental element to make well-informed purchasing decisions.

Although we are faced with decisions related to money management at an early age, such as having our first piggy bank or saving for a school trip, the main source of financial literacy of children is the family, in which they usually learn by observing the economic activity of the family environment [2]. The learning, savings culture, and strategic activities, such as the habit of budgeting, are transmitted. This teaching process allows people to learn what is necessary to cope with life, but it may not be enough to develop what Robert Kiyosaki calls financial intelligence, which he defines as the ability to solve financial problems [3].

Although financial intelligence is considered as a fundamental competence for modern life, it has not yet been addressed in the educational context with the importance it warrants. An important factor is related to students expressing interest in financial education, but professors have not been prepared to teach this subject [4]. This situation is attributable 
to the absence of this subject in their professional training and is therefore reflected in a general lack of knowledge that continues to directly affect the educational process of children and young people, who are future consumers.

Regardless of Chile's progress in education, specifically in that a significant percentage of young people now have free access to higher education, this does not necessarily indicate that consumer financial education has improved, because the government does not require this topic to be included in the professional curriculum. Society has not focused its efforts on improving the criteria related to personal financial management, and the main objectives seem to be directed at individual training and earning money without the support of educational programs that encourage responsible spending and savings. This situation represents a latent danger when choosing a financial product, because of a lack of knowledge of the duties and rights of the consumer.

The present study focused on university students, and its objective was to reveal the level of knowledge, behavior, and attitudes toward financial education, and it addressed the management of concepts and attitudes related to daily life. The following sections provide current background information, in which young people have been the focus of several studies that have attempted to understand their financial behavior and have aimed at developing educational strategies to raise awareness among the population on financial education topics. All this information was directed at improving consumer behavior and reducing indebtedness.

\section{Financial Education}

One of the main benefits of financial education is the ability to make decisions to maximize resources in personal financial management. This ability requires the development of habits and an objective analysis when making transactions; it also involves a permanent commitment to learning and acquiring knowledge that allows efficient decision-making that benefits one's economic wellbeing. In relation to this, it has been shown that long-term savings and investment contribute to people's financial security; in turn, these actions are directly related to the level of knowledge, showing that the accumulation of wealth destined for their retirement benefits from financial education [5].

Studies indicate that the willingness to save and invest can be promoted by financial literacy from childhood [6]. At this point, it is important to establish that on the one hand, financial literacy is characterized by an initial stage that seeks to know and relate the essential financial concepts for personal finance, while financial education aims to develop fundamental skills to make decisions financial.

It has been determined that financial education has positive effects on people's emotional development, financial knowledge and culture, is related to high levels of selfconfidence, and reduces anxiety states when dealing with economic issues $[7,8]$. Meanwhile, on the contrary, the absence of financial education is related to planning problems, a greater dependence on social benefits and economic deficiencies that lead to a state of insecurity [9].

Regarding its definition, according to the Organization for Economic Cooperation and Development (OECD), financial education is defined as:

"The process by which financial consumers/investors improve their understanding of financial products, concepts and risks and, through information, instruction and/or objective advice, develop the skills and confidence to become more aware of financial risks and opportunities, to make informed choices, to know where to go for help, and to take other effective actions to improve their financial well-being."

This definition has become especially meaningful in Chile since retailization [11] occurred in the 1990s, and has contributed many jobs to the economy, mainly from the establishment of supermarkets and department stores. This reality has promoted consumerism among the population by offering everyone a variety of financial instruments that facilitate the access to goods and services. These instruments provide credit to house- 
holds and generate dependency in individuals, who allocate a certain percentage of their monthly salary to pay debts. These debts multiply in times of crisis, such as the current COVID-19 pandemic, which has affected the economy, reduced household income, and forced families to take on debt to cover their basic living expenses.

Despite the efforts of various public and private institutions, financial education initiatives reported in Latin America are not sufficient to promote and educate the population on topics that can improve their personal finances [12]. Other determining variables are also identified that influence the abilities and knowledge about this topic, such as soft and numerical skills. It is essential to consider that a significant percentage of young people enrolled in school fail to achieve a basic level in reading, mathematics, and science, as reflected in the results of the Program for International Student Assessment (PISA).

According to the assessment of financial competencies in PISA 2018, and when analyzing the percentage of students who do not reach the basic competency level in this area, our region faces a significant challenge. Brazil has $43 \%$ of students who are unable to reach the basic level, while Peru has $46 \%$ and Chile has 30\%; meanwhile, the OECD average is only $22 \%$. This background information reflects the need to develop programs and strategies to improve these results. In addition, the financial well-being of families must be improved by implementing holistic, complementary, and progressive teaching at all educational levels so that future generations can develop an early knowledge of their personal finances.

It is important to highlight that despite the financial inclusion programs and strategies in our region, a large part of the Latin American population does not have access to formal financial services; however, a significant increase has been achieved for the most vulnerable sectors. Some of the main barriers to financial inclusion are cognitive biases, lack of trust in financial institutions, cost, low income and lack of access to financial services, also called "financial exclusion" [13]. At this point, based on data provided by the Global Findex on financial inclusion, among households worldwide, $50 \%$ of adults who do not participate in the banking system belong to the poorest households, mainly affecting women and minorities, such as the migrant population or indigenous peoples, and those who settle in remote rural sectors away from big cities, a situation that has generated a gap that mainly affects the financial development of women living in rural areas [14]. This situation needs to be reversed by means of the financial inclusion strategies implemented by each country, led by Chile, Brazil, Costa Rica and Uruguay, with scores above the LAC average [15], where it is demonstrated and recognized that people need financial literacy to properly access and use existing products [16].

Although there is a deficiency in this area, efforts to increase the financial inclusion of the population and the ease of access to credit, derived from the wide range and diversity of instruments, has allowed more and more people to cover basic needs such as healthcare, education, and housing. This scenario offers many possibilities and benefits for consumers, but also represents a danger for the finances of vulnerable families, because it exposes them to over-indebtedness. Over-indebtedness is defined as a situation in which the family group is unable to meet its financial obligations, and its future income is compromised by current consumption.

In line with the abovementioned observations, a study by Plata and Caballero [17] concluded that the main causes associated with debt are misinformation, irresponsible financial behavior, and the financial capability and skills of the clients. Therefore, financial education once again takes center stage. When projecting the benefits that it can generate in the long term for the population, it becomes a fundamental area for personal development, and it should aim at educating informed consumers who are responsible for their purchasing decisions and are capable of solving problems related to their personal finances.

\section{Advances in Chile and Latin America}

Chile has historically been one of the most stable economies in Latin America. the country's middle class has been able to expand over time, thus reducing the number of 
inhabitants considered as vulnerable. However, Chile leads the OECD countries as one of the most unequal in socioeconomic matters. This gap has directly influenced aspects such as the existing financial exclusion in the country, which has strongly affected the most disadvantaged groups.

Access to the commercial world and the acquisition of credit accounts begins with the coming of age. Young people therefore become a potential market for banking and commercial institutions that offer financial products such as credit cards and bank accounts. This situation is experienced on a massive scale during the university years, specifically when students receive various offers to manage their first current account; this provides them with an alternative for satisfying needs that may or may not be a priority.

Young people in Chile only understand finances from a domestic perspective and their experience based on what they can observe in their homes. This is currently considered detrimental, because the behavior of the average Chilean consumer shows that more than $70 \%$ of income is committed to debt; this situation has been highlighted by data provided by the OECD, the Superintendence of Banks and Financial Institutions (SBIF), and the Central Bank of Chile. In addition, few financial education programs have been identified that are aimed at young people and female heads of households [18]. These target groups could make a great difference in future generations if they were provided with financial education, because young people are those being formed and can generate structural changes in the long term. Meanwhile, female heads of households are those who are responsible in many cases for managing family resources and can provide the basics of financial education to their children; they can also gradually modify the purchasing, saving, and investment habits of the family.

Therefore, financial education strategies implemented in Chile should be aimed at developing skills that benefit the well-being of families. These strategies should encourage the need for knowledge among adults so as to improve their financial behavior, raise awareness among young people about the effects of over-indebtedness, and support the learning of children through an early introduction to financial concepts [19].

A review of some cases in Latin America has shown various experimental initiatives that have successfully influenced the learning process of individuals. According to the OECD study entitled "National Strategies for Inclusion and Financial Literacy in Latin America and the Caribbean: Implementation Challenges" [20], Peru, Mexico, Brazil, and Columbia have demonstrated benefits for the different groups involved, such as schools, workers, women, small- and medium-sized enterprises (SMEs), and the rural population. Based on the work of Verónica Frisancho [21], it has been shown that financial education has positive effects on students, including improved self-control, and therefore direct benefits for decision making. Other positive effects are related to the results reported by teachers who provided training. The participants showed a more genuine and appropriate interest in the subject, which led them to apply many of the teachings to their daily lives.

Despite evidence from several studies [22-25] that some neighboring countries have managed to encourage financial education among the population and thus positively influence different social groups, there is as yet no indication of any long-term followup. However, as in other subjects taught at an early age, the long-term benefits directly depend on raising awareness in families about the importance of good personal and family financial management. The teaching and dissemination of good practices on this matter aims at gradually developing a generational contribution that will become more and more apparent over time.

\section{Methodology}

The objective of this study was to analyze the level of knowledge, behavior and attitudes towards financial education among university students belonging to a public university in southern Chile. For this, the aim was to answer the question, do university students have knowledge about financial education? The results are expected to provide an approach to the reality of the country. 
The results are intended to provide relevant information for the implementation of strategies that can strengthen the financial education of future professionals, also identifying the issues that need to be reinforced from the analyzed sample.

The instrument used corresponds to an adaptation of the Survey of Measurement of Financial Capabilities in Chile 2016, and was delivered to us by the Commission of the Financial Market of Chile (CMF) in order to evaluate the knowledge and behavior of university students.

\subsection{Data and Method}

The target population was made up of students from a public university in southern Chile interested in financial education; a non-probability and convenience sampling was carried out to measure this population. The data were collected through the application of an online questionnaire and the students interested in participating were contacted by email, where the link that allowed them to record their background and responses was shared, thus achieving a sample of 410 respondents. The following were considered as required control variables: Chilean DNI (RUT), place of birth and marital status; this made it possible to verify their reliability. The factors that could predict the financial education and financial knowledge of the participants were determined by fitting a multinomial logistic regression model to the responses; this model was used to predict the probabilities of the different possible outcomes [26]. Multinomial logistic regression was used to predict categorical variables or the probability of category membership in a dependent variable based on multiple independent variables [27]. As in binary logistic regression, multinomial logistic regression uses maximum likelihood estimation to evaluate the probability of categorical membership. This type of model allowed us to characterize the probability associated with a respondent's decision regarding a particular multinomial discrete choice, which was conditional based on the values of the explanatory variables [28]. The distribution functions that characterize the explanatory variables are often not linear. Once the multinomial regression model was built, the parameters were used to predict the probability of an event occurring compared to the reference category.

In this particular case, our aim was to discover how the changes in the abovementioned independent variables affected the probabilities of the dependent variable in Equation (1), expressed as

$$
P\left(Y=j / X_{1}, X_{2}, \ldots, X_{k}\right)=P(Y=j / K) ; j=0,1, \ldots, J
$$

For the multinomial case, response probabilities are represented in Equations (2) and (3) as

$$
\begin{gathered}
P(Y=j / X)=\frac{\exp \left(X \beta_{j}\right)}{1+\sum_{h=1}^{J} \exp \left(X \beta_{h}\right)}=p_{j}(X, \beta) ; j=1, \ldots, J \\
P(Y=0 / X)=\frac{1}{1+\sum_{h=1}^{J} \exp \left(X \beta_{h}\right)}=p_{0}(X, \beta)
\end{gathered}
$$

Maximum likelihood was used to estimate multinomial logit models in which the logarithm of the likelihood function, which usually provides consistent and asymptotically normal estimators, is expressed in Equation (4) as

$$
l(\beta)=\sum_{i=1}^{n} \sum_{j=0}^{J} 1\left[Y_{i}=j\right] \log \left[p_{j}\left(X_{i}, \beta\right)\right]
$$

\subsection{Study Area}

The study had the participation of 410 students, who represent a limited number of students, and thus it is not possible to generalize the findings. However, the analysis allows for generating an approach to the reality of financial education in university 
students in order to advance in the theoretical study of this matter. According to the characterization of the collected antecedents, $61 \%$ of the participants are men, the majority are between 18 and 23 years old $(75 \%)$, and were in the process of professional training in the following programs:

$\begin{array}{ll}\checkmark & \text { Electrical Engineering } \\ \checkmark & \text { Mechanical Engineering } \\ \checkmark & \text { Electrical Engineering Technician } \\ \checkmark & \text { Associate of Science } \\ \checkmark & \text { Automation Engineering } \\ \checkmark & \text { Chemical Engineering } \\ \checkmark & \text { Computer Engineering Technician } \\ \checkmark & \text { Public Accountant and Auditor } \\ \checkmark & \text { Wood Technology Engineering } \\ \checkmark & \text { Architecture }\end{array}$

\section{Results}

\subsection{Descriptive Analysis}

Compared with other Chilean adults, only $5 \%$ of the total number of participants reported having a "very superior" level of knowledge of topics related to financial education, and 33\% reported having an "inferior or very inferior" level of knowledge.

Regarding household money management and decisions, 63\% declared that they participated jointly with a family member or partner. Only $12 \%$ of these respondents indicated they were in charge, and 50\% indicated that they personally supervised their financial matters. Another important aspect is that $40 \%$ of the sample recognized that their household had a budget, which is also related to financial control and a savings culture; only $16 \%$ of the sample declared that they had not been saving in the last 12 months.

Other significant aspects related to purchasing behavior and decisions were also identified; only $2 \%$ disagreed with analyzing whether they could pay for something before buying it, and 3\% expressed some degree of disagreement when asked whether they paid their bills on time.

As for the use of financial products, some students declared having a current account $(24 \%)$, credit card (15\%), and retail store credit (7\%). Meanwhile, 29\% acknowledged having compared several products from different institutions before acquiring their most recent financial product.

The following results were obtained when students were asked about different concepts:

- $\quad 38.5 \%$ reported knowing about the voluntary retirement savings account

- $45.1 \%$ reported knowing about the AFP pension fund

- $52.3 \%$ reported knowing about the cash advance

- $38.0 \%$ reported knowing about the car loan with specialized entities

- $30.0 \%$ reported knowing about credit with specialized consumer divisions

- $42.4 \%$ reported knowing about consumer credit

- $28.8 \%$ reported knowing about credit in cooperatives

- $44.4 \%$ reported knowing about the house mortgage loan

- $41.5 \%$ reported knowing about retail store credit

- $32.9 \%$ reported knowing about credit in compensation funds

- $25.9 \%$ reported knowing about microcredit

- $39.5 \%$ reported knowing about term deposits

- $23.7 \%$ reported knowing about factoring

- $26.1 \%$ reported knowing about leasing

- $43.2 \%$ reported knowing about types of insurance

- $34.6 \%$ reported knowing about obligatory personal accident insurance (SOAP)

- $34.4 \%$ reported knowing about supplemental health insurance

- $45.4 \%$ reported knowing about the savings account

- $41.2 \%$ reported knowing about the checkless bank account 
- $42.2 \%$ reported knowing about the current account

- $39.8 \%$ reported knowing about the line of credit

- $39.3 \%$ reported knowing about debit cards

- $46.8 \%$ reported knowing about checks

- $\quad 38.8 \%$ reported knowing about stock market investment/mutual funds

A significant portion of the sample stated that they were familiar with banking concepts and products, as well as pension funds and voluntary retirement savings accounts. However, financial education should be promoted among future professionals during their academic training to encourage inclusion and reduce the knowledge gap on this subject.

\subsection{Multinomial Logistic Regression}

The research objective was addressed by fitting a multinomial logistic regression model to determine the education and financial knowledge of the university students participating in the study. Table 1 summarizes the cases related to student knowledge related to financial education. A linear model was first run on the responses as a function of the predictors to ensure that there were no problems with multicollinearity; only predictors with variance inflation factors $(\mathrm{VIF})<2$ were included in these models [29]. The general form of our model is represented as follows:

Table 1. Model variable descriptor of multinomial logistic regression.

\begin{tabular}{|c|c|c|c|c|}
\hline Question & Variable & Alternatives & $\mathbf{N}$ & Marginal Percentage \\
\hline \multirow{3}{*}{$\begin{array}{l}\text { Imagine that five siblings receive a donation/gift of } \\
\text { CLP 1,000,000 ( } 1 \text { million Chilean pesos). If they have } \\
\text { to share the money equally, how much does each one } \\
\text { receive? }\end{array}$} & \multirow{3}{*}{ Division } & CLP 200,000 & 308 & $75.1 \%$ \\
\hline & & Another answer & 9 & $2.2 \%$ \\
\hline & & Do not know / No answer & 93 & $22.7 \%$ \\
\hline \multirow{5}{*}{$\begin{array}{l}\text { Now imagine that the siblings have to wait } 1 \text { year to } \\
\text { retrieve their share of the CLP } 1 \text { million from the safe, } \\
\text { and that inflation remains at } 3 \% \text { per year. What will } \\
\text { they be able to buy with the money after } 1 \text { year? }\end{array}$} & \multirow{5}{*}{ Value of money } & $\begin{array}{l}\text { More than they would be able } \\
\text { to buy today }\end{array}$ & 31 & $7.6 \%$ \\
\hline & & The same amount & 49 & $12.0 \%$ \\
\hline & & $\begin{array}{l}\text { Less than they would be able } \\
\text { to buy today }\end{array}$ & 198 & $48.3 \%$ \\
\hline & & $\begin{array}{l}\text { Depends on what they want } \\
\text { to buy }\end{array}$ & 38 & $9.3 \%$ \\
\hline & & Do not know / No answer & 94 & $22.9 \%$ \\
\hline \multirow{3}{*}{$\begin{array}{l}\text { Imagine that you lent CLP 20,000 to a friend one } \\
\text { evening and he paid you back CLP 20,000 the next } \\
\text { day, did your friend pay any interest on this loan? }\end{array}$} & \multirow{3}{*}{ Interest } & Yes & 4 & $1.0 \%$ \\
\hline & & No & 313 & $76.3 \%$ \\
\hline & & Do not know / No answer & 93 & $22.7 \%$ \\
\hline \multirow{5}{*}{$\begin{array}{l}\text { At a constant } 2 \% \text { interest rate, how much money } \\
\text { would the account have at the end of } 5 \text { years? (not } \\
\text { including commissions and taxes) }\end{array}$} & \multirow{5}{*}{ Compound interest } & More than CLP 110,000 & 150 & $36.6 \%$ \\
\hline & & Exactly CLP 110,000 & 102 & $24.9 \%$ \\
\hline & & Less than CLP 110,000 & 25 & $6.1 \%$ \\
\hline & & $\begin{array}{l}\text { Impossible to say with the } \\
\text { available information }\end{array}$ & 9 & $2.2 \%$ \\
\hline & & Do not know / No answer & 124 & $30.2 \%$ \\
\hline \multirow{3}{*}{$\begin{array}{l}\text { A high inflation rate means that the cost of living is } \\
\text { rising rapidly. }\end{array}$} & \multirow{3}{*}{ Inflation } & True & 259 & $63.2 \%$ \\
\hline & & False & 57 & $13.9 \%$ \\
\hline & & Do not know / No answer & 94 & $22.9 \%$ \\
\hline \multirow{3}{*}{$\begin{array}{l}\text { You are less likely to lose all your money if you invest } \\
\text { it in more than one place (diversification). }\end{array}$} & \multirow{3}{*}{ Diversification } & True & 203 & $49.5 \%$ \\
\hline & & False & 113 & $27.6 \%$ \\
\hline & & Do not know / No answer & 94 & $22.9 \%$ \\
\hline \multirow{6}{*}{$\begin{array}{l}\text { Prior to purchasing something, I carefully consider } \\
\text { whether I can afford it. }\end{array}$} & \multirow{6}{*}{ Prior to purchase } & Strongly disagree & 8 & $2.0 \%$ \\
\hline & & Disagree & 0 & $0.0 \%$ \\
\hline & & Neither agree nor disagree & 6 & $1.5 \%$ \\
\hline & & Agree & 38 & $9.3 \%$ \\
\hline & & Strongly agree & 218 & $53.2 \%$ \\
\hline & & Do not know/No answer & 140 & $34.1 \%$ \\
\hline
\end{tabular}


Table 1. Cont.

\begin{tabular}{|c|c|c|c|c|}
\hline Question & Variable & Alternatives & $\mathbf{N}$ & Marginal Percentage \\
\hline \multirow{6}{*}{ I personally monitor my financial matters. } & \multirow{6}{*}{ My finances } & Strongly disagree & 5 & $1.2 \%$ \\
\hline & & Disagree & 8 & $2.0 \%$ \\
\hline & & Neither agree nor disagree & 13 & $3.2 \%$ \\
\hline & & Agree & 48 & $11.7 \%$ \\
\hline & & Strongly agree & 204 & $49.8 \%$ \\
\hline & & Do not know/No answer & 132 & $32.2 \%$ \\
\hline \multirow{10}{*}{$\begin{array}{l}\text { In the last } 12 \text { months, have you been saving money in } \\
\text { any of the following ways (whether or not you still } \\
\text { have the money)? }\end{array}$} & \multirow{10}{*}{ Savings } & Save at home & 76 & $18.5 \%$ \\
\hline & & $\begin{array}{l}\text { Make a money pool with } \\
\text { friends }\end{array}$ & 3 & $0.7 \%$ \\
\hline & & $\begin{array}{l}\text { Purchase financial investment } \\
\text { products other than mutual } \\
\text { funds }\end{array}$ & 8 & $2.0 \%$ \\
\hline & & $\begin{array}{l}\text { Give money to your family to } \\
\text { save on your behalf }\end{array}$ & 6 & $1.5 \%$ \\
\hline & & $\begin{array}{l}\text { Leave money in savings or } \\
\text { current account }\end{array}$ & 73 & $17.8 \%$ \\
\hline & & $\begin{array}{l}\text { Deposit money in an } \\
\text { account/term deposit }\end{array}$ & 20 & $4.9 \%$ \\
\hline & & $\begin{array}{l}\text { Frequently deposit in savings } \\
\text { account }\end{array}$ & 14 & $3.4 \%$ \\
\hline & & $\begin{array}{l}\text { Save in other ways such as } \\
\text { buying property or other } \\
\text { types of assets }\end{array}$ & 2 & $0.5 \%$ \\
\hline & & Have not been actively saving & 66 & $16.1 \%$ \\
\hline & & No answer & 142 & $34.6 \%$ \\
\hline \multirow{2}{*}{ Do you have a cash advance? } & \multirow{2}{*}{ Have cash advance } & No & 388 & $94.6 \%$ \\
\hline & & Yes & 22 & $5.4 \%$ \\
\hline \multirow{2}{*}{ Have you had a cash advance? } & \multirow{2}{*}{ Have had cash advance } & No & 386 & $94.1 \%$ \\
\hline & & Yes & 24 & $5.9 \%$ \\
\hline \multirow{2}{*}{$\begin{array}{l}\text { Have you had a car loan with specialized entities } \\
\text { (e.g., FORUM or TANNER)? }\end{array}$} & \multirow{2}{*}{ Have had a car loan } & No & 402 & $98.0 \%$ \\
\hline & & Yes & 8 & $2.0 \%$ \\
\hline \multirow{2}{*}{$\begin{array}{l}\text { Do you know about credit with specialized consumer } \\
\text { divisions (SCD)? }\end{array}$} & \multirow{2}{*}{ Know about SCD credit } & No & 287 & $70.0 \%$ \\
\hline & & Yes & 123 & $30.0 \%$ \\
\hline \multirow{2}{*}{$\begin{array}{l}\text { Do you have credit with specialized consumer } \\
\text { divisions (SCD)? }\end{array}$} & \multirow{2}{*}{ Have credit with SCD } & No & 396 & $96.6 \%$ \\
\hline & & Yes & 14 & $3.4 \%$ \\
\hline \multirow{2}{*}{$\begin{array}{l}\text { Have you had credit with specialized consumer } \\
\text { divisions (SCD)? }\end{array}$} & \multirow{2}{*}{ Have had credit with SCD } & No & 404 & $98.5 \%$ \\
\hline & & Yes & 6 & $1.5 \%$ \\
\hline \multirow{2}{*}{ Have you had checks? } & \multirow{2}{*}{ Have had checks } & No & 390 & $95.1 \%$ \\
\hline & & Yes & 20 & $4.9 \%$ \\
\hline \multirow{2}{*}{ Do you know about the current account? } & \multirow{2}{*}{$\begin{array}{l}\text { Know about current } \\
\text { account }\end{array}$} & No & 237 & $57.8 \%$ \\
\hline & & Yes & 173 & $42.2 \%$ \\
\hline \multirow{2}{*}{ Do you have a current account? } & \multirow{2}{*}{ Have a current account } & No & 310 & $75.6 \%$ \\
\hline & & Yes & 100 & $24.4 \%$ \\
\hline \multirow{2}{*}{ Do you know about the savings account? } & \multirow{2}{*}{$\begin{array}{l}\text { Know about savings } \\
\text { account }\end{array}$} & No & 224 & $54.6 \%$ \\
\hline & & Yes & 186 & $45.4 \%$ \\
\hline 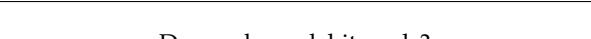 & & No & 242 & $59.0 \%$ \\
\hline & & Yes & 168 & $41.0 \%$ \\
\hline Do you have a voluntary retirement savings account & Hom & No & 403 & $98.3 \%$ \\
\hline$(\mathrm{APV}) ?$ & Have APV & Yes & 7 & $1.7 \%$ \\
\hline Have you had a voluntary retirement savings & Ho & No & 403 & $98.3 \%$ \\
\hline account $(\mathrm{APV}) ?$ & Have nad Arv & Yes & 7 & $1.7 \%$ \\
\hline H & & No & 399 & $97.3 \%$ \\
\hline & Mave nad ArT & Yes & 11 & $2.7 \%$ \\
\hline
\end{tabular}


Table 1. Cont.

\begin{tabular}{|c|c|c|c|c|}
\hline Question & Variable & Alternatives & $\mathbf{N}$ & Marginal Percentage \\
\hline \multirow{2}{*}{ Do you know about credit in cooperatives? } & \multirow{2}{*}{$\begin{array}{l}\text { Know about credit in } \\
\text { cooperatives }\end{array}$} & No & 292 & $71.2 \%$ \\
\hline & & Yes & 118 & $28.8 \%$ \\
\hline \multirow{2}{*}{ Do you have credit in cooperatives? } & \multirow{2}{*}{ Have credit in cooperatives } & No & 407 & $99.3 \%$ \\
\hline & & Yes & 3 & $0.7 \%$ \\
\hline \multirow{2}{*}{ Do you have a line of credit? } & \multirow{2}{*}{ Have a line of credit } & No & 368 & $89.8 \%$ \\
\hline & & Yes & 42 & $10.2 \%$ \\
\hline \multirow{2}{*}{ Do you have retail store credit? } & \multirow{2}{*}{ Have retail store credit } & No & 381 & $92.9 \%$ \\
\hline & & Yes & 29 & $7.1 \%$ \\
\hline \multirow{2}{*}{ Do you know about leasing? } & \multirow{2}{*}{ Know about leasing } & No & 303 & $73.9 \%$ \\
\hline & & Yes & 107 & $26.1 \%$ \\
\hline \multirow{2}{*}{ Do you use leasing? } & \multirow{2}{*}{ Use leasing } & No & 406 & $99.0 \%$ \\
\hline & & Yes & 4 & $1.0 \%$ \\
\hline \multirow{2}{*}{ Do you perform factoring? } & \multirow{2}{*}{ Perform factoring } & No & 408 & $99.5 \%$ \\
\hline & & Yes & 2 & $0.5 \%$ \\
\hline \multirow{2}{*}{ Do you have a house mortgage loan? } & \multirow{2}{*}{$\begin{array}{c}\text { Have a house mortgage } \\
\text { loan }\end{array}$} & No & 403 & $98.3 \%$ \\
\hline & & Yes & 7 & $1.7 \%$ \\
\hline \multirow{2}{*}{ Do you have consumer credit? } & \multirow{2}{*}{ Have consumer credit } & No & 399 & $97.3 \%$ \\
\hline & & Yes & 11 & $2.7 \%$ \\
\hline \multirow{2}{*}{ Have you had consumer credit? } & \multirow{2}{*}{ Have had consumer credit } & No & 400 & $97.6 \%$ \\
\hline & & Yes & 10 & $2.4 \%$ \\
\hline \multirow{2}{*}{ Do you know about the SOAP insurance? } & \multirow{2}{*}{$\begin{array}{l}\text { Know about SOAP } \\
\text { insurance }\end{array}$} & No & 268 & $65.4 \%$ \\
\hline & & Yes & 142 & $34.6 \%$ \\
\hline \multirow{2}{*}{ Have you had SOAP insurance? } & \multirow{2}{*}{ Have had SOAP insurance } & No & 393 & $95.9 \%$ \\
\hline & & Yes & 17 & $4.1 \%$ \\
\hline \multirow{2}{*}{ Have you had supplemental health insurance? } & \multirow{2}{*}{$\begin{array}{l}\text { Have had supplemental } \\
\text { health insurance }\end{array}$} & No & 399 & $97.3 \%$ \\
\hline & & Yes & 11 & $2.7 \%$ \\
\hline \multirow{2}{*}{ Do you have a credit card? } & \multirow{2}{*}{ Have credit card } & No & 347 & $84.6 \%$ \\
\hline & & Yes & 63 & $15.4 \%$ \\
\hline \multirow{2}{*}{ Have you had a credit card? } & Havo bad croditcord & No & 390 & $95.1 \%$ \\
\hline & 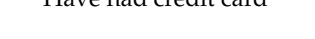 & Yes & 20 & $4.9 \%$ \\
\hline & & Yes, it has happened & 130 & $31.7 \%$ \\
\hline Sometimes people find that their income is not & & No, it has not happened & 72 & $17.6 \%$ \\
\hline $\begin{array}{l}\text { enough to cover their expenses. Has this happened } \\
\text { to you in the last } 12 \text { months? }\end{array}$ & Insolvency & $\begin{array}{l}\text { Not applicable (have no } \\
\text { personal income) }\end{array}$ & 68 & $16.6 \%$ \\
\hline & & No answer & 140 & $34.1 \%$ \\
\hline
\end{tabular}

The dependent variable has only one value observed in 315 (98.1\%) subjects.

Knowledge $=\mathrm{f}$ (division, value of money, interest, compound interest, inflation, diversification, prior to purchase, my finances, savings, have cash advance, have had cash advance, have had a car loan, know about credit with SCD, have credit with SCD, have had credit with SCD, have had checks, know about current account, have a current account, know about savings account, have a debit card, have APV, have had APV, have had AFP, know about credit in cooperatives, have credit in cooperatives, have line of credit, have retail store credit, know about leasing, use leasing, perform factoring, have a house mortgage loan, have consumer credit, have had consumer credit, know about SOAP insurance, have had SOAP insurance, have had supplemental health insurance, have a credit card, have had a credit card, insolvency).

For the fitted model information, the chi-squared ratio test value was $614.404(\mathrm{df}=845$; $p=0.000$ ), which indicated a good model fit. Acceptable values were also obtained for the pseudo R-squared (Cox and Snell: 0.777, Nagelkerke: 0.810). Table 2 shows that the power of our logistic multinomial model was suitable because it correctly classified $81 \%$ of the known observations and can be expected to project future estimates. Table 3 displays the 
likelihood ratio tests for the effects of the model and the partials whose low $p$-values show the high significance of the variables in the model

Table 2. Power of classification of citizen model.

\begin{tabular}{|c|c|c|c|c|c|c|c|}
\hline \multirow[b]{2}{*}{ Observed } & \multicolumn{7}{|c|}{ Predicted } \\
\hline & Very Superior & Superior & Average & Inferior & Very Inferior & $\begin{array}{c}\text { Do Not Know/No } \\
\text { Answer }\end{array}$ & $\begin{array}{l}\text { Percent } \\
\text { Correct }\end{array}$ \\
\hline Very superior & 14 & 1 & 4 & 0 & 0 & 0 & $73.7 \%$ \\
\hline Superior & 2 & 54 & 11 & 1 & 3 & 0 & $76.1 \%$ \\
\hline Average & 1 & 1 & 149 & 1 & 0 & 0 & $98.0 \%$ \\
\hline Inferior & 0 & 0 & 22 & 61 & 2 & 0 & $71.8 \%$ \\
\hline Very inferior & 0 & 2 & 8 & 1 & 40 & 0 & $78.4 \%$ \\
\hline Do not know/no answer & 0 & 0 & 18 & 0 & 0 & 14 & $43.8 \%$ \\
\hline Overall Percentage & $4.1 \%$ & $14.1 \%$ & $51.7 \%$ & $15.6 \%$ & $11.0 \%$ & $3.4 \%$ & $81.0 \%$ \\
\hline
\end{tabular}

Table 3. Multinomial logistic regression of citizen model.

\begin{tabular}{|c|c|c|c|c|}
\hline \multirow{2}{*}{ Effect } & \multirow{2}{*}{$\begin{array}{c}\text { Model Fitting Criteria } \\
-2 \text { Log Likelihood of Reduced Model }\end{array}$} & \multicolumn{3}{|c|}{ Likelihood Ratio Tests } \\
\hline & & Chi-Squared & Degrees of Freedom & $p$-Value \\
\hline Intercept & 479.610 & 0.000 & 0 & \\
\hline Division & 925.542 & 445.933 & 5 & 0.000 \\
\hline Value of money & 595.029 & 115.419 & 20 & 0.000 \\
\hline Interest & 1180.215 & 700.606 & 10 & 0.000 \\
\hline Compound interest & $721,535.089$ & $721,055.479$ & 20 & 0.000 \\
\hline Inflation & 628.644 & 149.034 & 10 & 0.000 \\
\hline Diversification & 1917.900 & 1438.290 & 10 & 0.000 \\
\hline Prior to purchase & 867.076 & 387.466 & 20 & 0.000 \\
\hline My finances & 2719.049 & 2239.439 & 25 & 0.000 \\
\hline Savings & 557.677 & 78.067 & 45 & 0.002 \\
\hline Have cash advance & 1135.188 & 655.578 & 5 & 0.000 \\
\hline Have had cash advance & 1311.501 & 831.891 & 5 & 0.000 \\
\hline Have had a car loan & 1069.474 & 589.865 & 5 & 0.000 \\
\hline Know about credit with SCD & 572.756 & 93.146 & 5 & 0.000 \\
\hline Have credit with SCD & 709.333 & 229.723 & 5 & 0.000 \\
\hline Have had credit with SCD & 765.323 & 285.714 & 5 & 0.000 \\
\hline Have had checks & 660.418 & 180.808 & 5 & 0.000 \\
\hline Know about current account & 677.615 & 198.005 & 5 & 0.000 \\
\hline Have a current account & 523.057 & 43.447 & 5 & 0.000 \\
\hline Know about savings account & 683.549 & 203.939 & 5 & 0.000 \\
\hline Have a debit card & 1587.942 & 1108.332 & 5 & 0.000 \\
\hline Have APV & 1103.442 & 623.832 & 5 & 0.000 \\
\hline Have had APV & 519.211 & 39.601 & 5 & 0.000 \\
\hline Have had AFP & 622.093 & 142.483 & 5 & 0.000 \\
\hline
\end{tabular}


Table 3. Cont.

\begin{tabular}{|c|c|c|c|c|}
\hline \multirow{2}{*}{ Effect } & \multirow{2}{*}{$\begin{array}{c}\text { Model Fitting Criteria } \\
-2 \text { Log Likelihood of Reduced Model }\end{array}$} & \multicolumn{3}{|c|}{ Likelihood Ratio Tests } \\
\hline & & Chi-Squared & Degrees of Freedom & $p$-Value \\
\hline $\begin{array}{l}\text { Know about credit in } \\
\text { cooperatives }\end{array}$ & 1707.297 & 1227.687 & 5 & 0.000 \\
\hline Have credit in cooperatives & 1411.415 & 931.805 & 5 & 0.000 \\
\hline Have line of credit & 1813.684 & 1334.074 & 5 & 0.000 \\
\hline Have retail store credit & 957.468 & 477.858 & 5 & 0.000 \\
\hline Know about leasing & 5299.049 & 4819.439 & 5 & 0.000 \\
\hline Use leasing & $261,893.325$ & $261,413.715$ & 5 & 0.000 \\
\hline Perform factoring & 1070.155 & 590.545 & 5 & 0.000 \\
\hline Have a house mortgage loan & 1648.540 & 1168.930 & 5 & 0.000 \\
\hline Have consumer credit & 578.911 & 99.301 & 5 & 0.000 \\
\hline Have had consumer credit & 742.729 & 263.119 & 5 & 0.000 \\
\hline Know about SOAP insurance & $28,320.248$ & $27,840.639$ & 5 & 0.000 \\
\hline Have had SOAP insurance & 1448.979 & 969.369 & 5 & 0.000 \\
\hline $\begin{array}{l}\text { Have had supplemental } \\
\text { health insurance }\end{array}$ & 1237.148 & 757.538 & 5 & 0.000 \\
\hline Have a credit card & 1013.773 & 534.163 & 5 & 0.000 \\
\hline Have had a credit card & 2961.696 & 2482.086 & 5 & 0.000 \\
\hline Insolvency & $278,596.149$ & $278,116.540$ & 15 & 0.000 \\
\hline
\end{tabular}

The different levels represented in the table were established considering the alternatives indicated in the original instrument: very superior, superior, average, inferior, and very inferior, and space was given to those who indicated do not know or simply prefer not to answer.

The results in Table 3 could indicate advances in the financial knowledge of the sample, directly related to recurring aspects of concern and socialization within families of different socioeconomic groups. In recent years, this has revealed tensions in the Chilean economic model. This study of university students is relevant because they are the generation that has recently entered higher education, and they have driven important social movements that have questioned, for example, their parents' quality of life and ability to ensure an adequate level of family consumption. They have also criticized sustained indebtedness or the conditions that certain financial institutions have imposed on these groups.

The variables highlighted in this model (Table 3) are significant for citizens who require this type of financial knowledge to survive/live and cope in a structural framework characterized by a series of features that situate the population in the real and contemporary Chile. In other words, they exist in a context that demonstrates unease, but also the need to increase access, services, and material goods in sectors of the middle class that now perceive a greater insecurity of losing what they achieved in recent decades as a result of the pandemic and regional economic crises.

The variables of division, value of money, interest, compound interest, and the understanding of inflation and diversification were significant for theoretical financial knowledge. We found that these elements are interrelated, regardless of whether these variables are part of the contents studied in undergraduate courses in the Chilean educational system, and even when viewed from a mathematical rather than a financial logic. The need to divide money among family members to spend on the activities and commercial commitments that each of them have is a situation that occurs at an early age in discussions between 
people. This is due to the demands of consumption generated by the progressive increase in the cost of living in Chile.

Therefore, the knowledge of aspects such as the interest charged on loans is not surprising, because these are priorities and concerns faced by citizens; for example, they have to finance their children's university education or education in general. This situation is openly expressed and is a matter of public debate. It is very likely that new generations of Chileans are growing up with this level of information and stress, which is often processed more emotionally than technically or financially.

We have also considered that the variables referring to the financial knowledge of the typical practices of these young people also include a significant circumstantial element that is based on a process of individual, family, and social expectations, which shows a way of prioritizing, understanding, and hierarchizing the financial dimension from the point of view of a certain section of the population. This analyzed population interacts at an early age with their material limitations and concerns, aspirations, and frustrations of their respective environments.

For example, the prior to purchase variable is significant because individuals think carefully about whether something can be purchased. In this case, it reflected a shortage of money that we believe is assumed with a sense of responsibility and prioritization of what is purchased. This also implies a willingness to personally monitor financial issues, thus confirming caution in decision making because the consequence of consumption behavior is assumed based on the lack of abundance or scarcity.

Likewise, savings apparently tend to be seen as a "must" in terms of values, including as an aspiration, either at the household level or in bank accounts. However, its practice is not very common due to the aforementioned restrictions of the domestic economy.

In fact, consumption in Chile is a vital and culturally rooted practice that has increased with the return to democracy and the implemented political transition. Although these advances are not very common in the average reality of young people, they are significant for the financial knowledge of the consumer environments in which they live, coexist, or that are symbolically presented to them by the mass media.

In addition, a car purchase is an aspect of belonging to the Chilean consumer society; it is essential for work and generating resources for various productive activities in the country. The car loan is therefore a significant variable with regard to its recognition and existence for young people. It is a priority that is declared in various Chilean socioeconomic sectors and exhibits another area of indebtedness that the students identified, most likely because of what they have experienced in their families or observed in society. It is not surprising that SOAP insurance emerges as a variable that explained the financial knowledge of these young people, because its existence is linked to car circulation or mobility in Chile.

The topic of consumer credit was reiterated by the variable of student knowledge and from the experience of the university students with this financial instrument (have credit with SCD and have had credit with SCD), an aspect that was replicated with retail store credit. Credit is present in the daily life of Chileans. It allows them to acquire what is necessary or that which ensures progressive material progress; however, it is also the only option for many families to pay for what their monthly salaries do not cover during these periods. People in Chile usually do not talk openly about their level of debt, but it is a constant concern that is shared in the private or intimate environment. Its magnitude was understood with the student movements in 2011 that proposed free higher education, mainly due to the interest rates of the loans that families obtained from the banks.

This model also highlights checks (have had checks), which used to be very important in Chile but have lost their relevance in recent years. At this stage of Chilean modernity, checks are a symbol that confirms the limitation of resources or the possibility of paying what is owed in installments; they also indicate a certain degree of status for young people.

The renewal of checks can be seen in aspects that explain current financial knowledge, and they are central to the Chilean system. On the one hand, university students cannot 
access these instruments, which are perceived as part of a consumer society that excludes, limits, or segregates. On the other hand, these variables allow them to achieve social integration and mobility that satisfy a series of ideals expressed in the public debate.

The knowledge and use of the current account, which in turn allows access to other products such as credit and debit cards, a line of credit, APV, as well as a savings account, are placed in this context. For a percentage of young people, these products may be perceived as unattainable, elusive, frustrating, or non-existent; financial knowledge is also needed to distinguish elements that operate with a view to the future, such as health insurance, AFP, and even mortgages or leasing.

Finally, insolvency was also perceived as significant, which confirms an experiencebased financial knowledge from within the reality in which young people live and is acquired through family, social, and university interactions.

\section{Discussion and Conclusions}

An in-depth study of financial education in Chile is very challenging and relevant, especially at a time when the country is experiencing crucial events that will define its future, such as the drafting of a new constitution. Furthermore, the fact that these studies are aimed at young people is even more important, because they will be the decision makers in the coming decades and need to be as well prepared as possible. Young people in Chile were the protagonists of the current political discussion triggered by the so-called "social uprising" in October 2019, which promoted discussions on the quality of education, the economic model, and inequality, among other issues of social and political interest [30,31].

The family is currently the main source of learning in financial education. Meanwhile, curricula in elementary, secondary, and university education do not provide adequate training for the current and future challenges in this area.

The present study was carried out to determine if the students of a public university in southern Chile have knowledge in financial education. Based on the results, it is possible to highlight that the majority of the young people recognized how the market for goods and services works, identified bank products and learned about the effects of installment purchases. However, only $5 \%$ of the sample had a much higher level of knowledge on financial education issues, and less knowledge was also identified on issues related to insurance, retirement savings, pension funds, and the effects of the exchange rate.

The challenge for higher education institutions is therefore to promote the learning of future professionals with regard to financial education topics, especially in developing attitudes and variables associated with behavior. Some topics suggested for further study are budgeting, purchasing decisions, and responsible indebtedness; this would enable young people to maximize their economic resources and seek to improve their family's economic well-being.

There are many areas for future work, such as comparative studies in different Chilean institutions of higher education and in other countries of the region. There are also analyses and proposals to improve curricula at the elementary, secondary, and university levels, and studies and proposals to be included in the current national social, economic, and political discussion, especially considering the actual pandemic situation [32-36].

Author Contributions: Formal analysis, H.d.1.F.-M., B.U.-H., M.F.-F. and C.E.-G.; funding acquisition, B.U.-H. and H.d.1.F.-M.; investigation, H.d.1.F.-M., B.U.-H., M.F.-F. and C.E.-G.; methodology, H.d.l.F.M. and M.F.-F.; project administration, B.U.-H.; software, H.d.l.F.-M.; supervision, B.U.-H. and M.F.-F.; validation, H.d.l.F.-M. and C.E.-G.; writing-original draft, B.U.-H. and M.F.-F.; writing-review and editing, H.d.l.F.-M. and C.E.-G. All authors have read and agreed to the published version of the manuscript.

Funding: Hanns de la Fuente-Mella and Claudio Elórtegui-Gómez were supported by a grant from the Núcleo de Investigación en Data Analytics/VRIEA/PUCV/039.432/2020.

Data Availability Statement: The data used to support the findings of this study are available from the corresponding author upon request. 
Acknowledgments: The authors thank the Editors and two Referees for their constructive comments on an earlier version of this manuscript, which resulted in this improved version.

Conflicts of Interest: The authors declare no conflict of interest.

\section{References}

1. Moreno-García, E.; García-Santillán, A.; Gutiérrez-Delgado, L. Nivel de educación financiera en escenarios de educación superior. Un estudio empírico con estudiantes del área económico-administrativa. Rev. Iberoam. Educ. Super. 2017, 8, 163-183. [CrossRef]

2. Cruz Barba, E. Educación financiera en los niños: Una evidencia empírica. Sinéctica 2018, 51. [CrossRef]

3. Kiyosaki, R.T. Padre Rico. Padre Pobre (Nueva Edición Actualizada): Qué les Enseñan los Ricos a sus Hijos ACERCA del Dinero; Aguilar: Cordoba, Spain, 2012.

4. Villada, F.; López-Lezama, J.M.; Muñoz-Galeano, N. El Papel de la Educación Financiera en la Formación de Profesionales de la Ingeniería. Form. Univ. 2017, 10, 13-22. [CrossRef]

5. Atkinson, A.; Messy, F.-A.; Rabinovich, L.; Yoong, J. Financial Education for Long-Term Savings and Investments: Review of Research and Literature; OECD Working Papers on Finance, Insurance and Private Pensions 39; OECD Publishing: Paris, France, 2015.

6. Valdivieso, G.D.C.P. Medición del conocimiento financier en los participantes de programas de educación financiera: Caso del Banco de Loja SA. Redmarka. Rev. Mark. Appl. 2017, 2, 47-60. [CrossRef]

7. Fox, J.; Bartholomae, S.; Lee, J. Building the case for financial education. J. Consum. Aff. 2005, 39, 195-214. [CrossRef]

8. Kim, J. Workplace financial education program: Does it have an impact on employee's personal finances. J. Fam. Consum. Sci. 2007, 99, 80-85.

9. Marrero, M.C.R. El desafío de una alfabetización financiera. Bus. Innova Sci. 2021, 2, 67-75.

10. Atkinson, A.; Messy, F. Promoting Financial Inclusion through Financial Education: OECD/INFE Evidence, Policies and Practice; OECD Working Papers on Finance, Insurance and Private Pensions, No. 34; OECD Publishing: Paris, France, 2013. [CrossRef]

11. Tapia, A.M. Endeudamiento "saludable", empoderamiento y control social. Polis. Revista Latinoamericana 2018, 17, 79-101. [CrossRef]

12. Gutiérrez Andrade, O.W.; Delgadillo Sánchez, J.A. La educación financiera en jóvenes universitarios del primer ciclo de pregrado de la Universidad Católica Boliviana "San Pablo", Unidad Académica Regional de Cochabamba. Rev. Perspect. $2018,41,33-72$.

13. Cea, M.; Sandoval, D.; Strello, A. Estudio de Alfabetización y Comportamiento Financiero en Chile; Centro de Politicas Públicas UC: Santiago, Chile, 2017.

14. Mejía, D.; Pallotta, A.; Egúsquiza, E. Encuesta de Medición de las Capacidades Financieras en los Países Andinos 2014; CAF: Lima, Peru, 2015.

15. Demirgüç-Kunt, A.; Leora, K.; Doro-the Singer, S.; Hess, A.J. La Base de Datos Global Findex 2017: Medición de la Inclusion Financiera y la Revolución de la Tecnología Financiera; Banco Mundial. Licencia: Creative Commons Attribution CC BY 3.0 IGO; Cuadernillo de Reseña: Washington, DC, USA, 2018.

16. Ormazábal, F.; Sepúlveda, A.; Silva, N. Encuesta de Medición de Capacidades Financieras en los Países Andinos: Chile 2016 report. Santiago de Chile: SBIF (Superintendencia de Bancos e Instituciones Financieras de Chile. Available online: http:/ / scioteca.caf.com/handle/123456789/985 (accessed on 24 April 2021).

17. Plata-Gómez, K.R.; Caballero-Márquez, J.A. Influencia de los programas de educación financiera sobre el comportamiento de los jóvenes: Una revisión de literatura. I + D Rev. Investig. 2020, 15, 18-27.

18. Eichhorn, K. Sobreendeudamiento de los Hogares en Chile: Determinantes y Recomendaciones de Política Pública. Ph.D. Thesis, Pontificia Universidad Católica de Chile, Santiago, Chile, 2020.

19. Servicio Nacional del Consumidor. La Educación Financiera en Jóvenes: Clave Para un Desarrollo Económico Saludable; Servicio Nacional del Consumidor: Santiago, Chile, 2015.

20. Grifoni, A.; Mejía, D.; Morais, S.; Ortega, S.; Roa, M.J. Estrategias Nacionales de Inclusión y Educación Financiera en América Latina y el Caribe: Retos de Implementación; OCDE/CAF: Paris, France, 2020.

21. Frisancho, V. The Impact of School-Based Financial Education on High School Students and Their Teachers: Experimental Evidence from Peru. 2018. Available online: http:/ / dx.doi.org/10.18235/0001056 (accessed on 24 April 2021).

22. García, N.; Grifoni, A.; López, J.C.; Mejía, D. N 12. La Educación Financiera en América Latina y el Caribe. Situación Actual y Perspectivas. 2013. Available online: http:/ / scioteca.caf.com/handle/123456789/379 (accessed on 24 April 2021).

23. Sinche, M.B.A.; Brito, R.V.C.; Delgado, M.M.S. Programas de Educación Financiera Implementados en América Latina. Rev. Investig. Form. Desarro. Generando Product. Inst. 2019, 7, 23.

24. López, J.B.C. Análisis de la necesidad de la educación financiera en la formación colegial. Pensam. Crit. 2017, $22,97-126$.

25. Roa, M.J.; Mejía, D. Decisiones Financieras de los Hogares e Inclusión Financiera: Evidencia para América Latina y el Caribe. 2018. Available online: http:/ / scioteca.caf.com/handle/123456789/1188 (accessed on 24 April 2021).

26. Coughenour, C.; Paz, A.; De la Fuente-Mella, H.; Singh, A. Multinomial logistic regression to estimate and predict perceptions of bicycle and transportation infrastructure in a sprawling metropolitan area. J. Public Health 2016, 38, e401-e408. [CrossRef] [PubMed]

27. Clark, S.; Coughenour, C.; Bumgarner, K.; De la Fuente-Mella, H.; Reynolds, C.; Abelar, J. The impact of pedestrian crossing flags on driver yielding behavior in Las Vegas, NV. Sustainability 2019, 11, 4741. [CrossRef]

28. Coughenour, C.; De la Fuente-Mella, H.; Paz, A. Analysis of self-reported walking for transit in a sprawling urban metropolitan area in the western U.S. Sustainability 2019, 11, 852. [CrossRef] 
29. Paz, A.; De la Fuente-Mella, H.; Singh, A.; Conover, R.; Monteiro, H. Highway expenditures and associated customer satisfaction: A case study. Math. Probl. Eng. 2016, 2016, 4630492. [CrossRef]

30. De la Fuente-Mella, H.; Guzmán, C.; Crawford, K.; Foschino, G.; Crawford, B.; Soto, R.; León de la Barra, C.; Cisternas-Caneo, F.; Monfroy, E.; Becerra-Rozas, M.; et al. Analysis and prediction of students' behavior and their relation to academic performance using data analytics techniques. Appl. Sci. 2020, 10, 7114. [CrossRef]

31. Cárdenas, C.; Crawford, K.; Crawford, B.; Soto, R.; De la Fuente-Mella, H.; Peña, A.; Valenzuela, M.; Hermosilla, P.; Álvarez, L. A quantitative analysis of the identification of personality traits in engineering students and their relation to academic performance. Stud. High. Educ. 2020, 45, 1323-1334. [CrossRef]

32. De la Fuente-Mella, H.; Vallina, A.M.; Solis, R. Stochastic analysis of the economic growth of OECD countries. Econ. Res. -Ekon. Istraživanja 2020, 33, 2189-2202. [CrossRef]

33. Vallina, A.M.; De la Fuente-Mella, H.; Solis, R. International Trade and Innovation: Delving in Latin American Commerce. Acad. ARLA 2020, 33, 535-547. [CrossRef]

34. De la Fuente-Mella, H.; Rubilar, R.; Chahuan, K.; Leiva, V. Modeling COVID-19 cases statistically and evaluating their effect on OECD economies. Mathematics 2021, 9, 1558. [CrossRef]

35. Chahuan, K.; Rubilar, R.; De la Fuente-Mella, H.; Leiva, V. Predictive modeling for pandemic COVID-19 and its effects on the global financial crisis. Entropy 2021, 23, 100. [CrossRef]

36. Umaña, B.; De la Fuente-Mella, H.; Elórtegui, C.; Fonseca, M. Multinomial Logistic Regression to Estimate and Predict the Perceptions of Individuals and Companies in the Face of the COVID-19 Pandemic in the Nuble Region, Chile. Sustainability 2020, 12, 9553. [CrossRef] 